\title{
Functional State of Workers Data Analysis in the Labor Process
}

\author{
Sergey Andreevich Faustov ${ }^{1}$, Vladimir Ivanovich Salkutsan ${ }^{1}$, Nikolay Aleksandrovich \\ Chumakov $^{1 *}$ \\ ${ }^{1}$ Peter the Great St.Petersburg Polytechnic University, Polytechnicheskaya, 29, St.Petersburg, 195251, \\ Russia
}

\begin{abstract}
It is shown that the state of working people, determined using the WAM technique, (well-being, activity, mood) has statistically significant correlation with the results of instrumental measurements in terms of changes in the physiological state of the same workers. It is proposed to use the WAM test as an independent method for determining the functional state of workers. The purpose of this work was to determine the ratio of the functional state of workers according to the instrumental assessment, on the one hand, and self-assessment of their state, on the other.
\end{abstract}

\section{Introduction}

Determining the functional status of those, working in real production requires the use of expensive equipment, often not commercially available and, as a result, not approved by metrological certification. In 1973, V.A. Doskin, N.A. Lavrent'eva, and others [1] proposed a blank method of differentiated self-esteem of the functional state of a person, including three components: well-being, activity, and mood (WAM). The category "well-being" includes characteristics that reflect strength, health, fatigue. The category of "activity" includes the characteristics of mobility, speed and pace of the processes. The category of "mood" refers to the characteristics of the emotional state. Each of the components contains 10 pairs of words with opposite meanings, for example, "active - passive", "happy unhappy", and a series of numbers for quantitative self-assessment, which are recoded when processing the questionnaire into a number of points from one to seven. WAM test is usually used in physiological and hygienic studies in conjunction with instrumental physiological methods.

\section{The technique}

The labor activity of 13 electric welders engaged in assembling and welding truck platforms was studied.

The parameters of welders' condition, obtained by instrumental methods, include: heart rate, muscle strength and endurance of the hand, indicators of coordinate measurement (maze

*Corresponding author: chumakov_na@spbstu.ru 
performance time and number of errors), critical light flicker fusion frequency, simple motor response to light, the closest point of clear vision for each eye.

These indicators are defined at the beginning, middle and end of the shift. Self-esteem of the tested people condition was obtained at the beginning and end of the shift using the WAM test. The data were calculated according to traditional parametric statistical methods. Mean values, average errors, coefficients of variation were calculated. Individual data of instrumental indicators and indicators of self-assessment were subjected to correlation analysis.

\section{Results}

Manual operations and operations with manual mechanized tools (about $75 \%$ on average) prevailed in the work of welders.

The severity of labor corresponded to class 2 in terms of hygienic criteria [2]. Slightly more than half of the shift, the welders were affected by welding aerosol and arc radiation.

Table 1 presents the basic data on the state of the production environment.

Table 1. Indicators of the condition of the industrial environment in the working places of electric welders.

\begin{tabular}{|c|c|c|}
\hline Indicator & Value of the indicator & $\begin{array}{l}\text { MPC, } \\
\text { MPL }\end{array}$ \\
\hline $\begin{array}{l}\text { Welding aerosol concentration } \\
\text { in the respiratory zone, } \mathrm{mg} / \mathrm{m} 3 \text { : } \\
\text { - in front of a face shield }\end{array}$ & 16,2 & - \\
\hline - under a face shield & 12,4 & - \\
\hline $\begin{array}{l}\text { Including, manganese: } \\
\text { - in front of a face shield }\end{array}$ & 0,8 & 0,2 \\
\hline - under a face shield & 1,2 & 0,2 \\
\hline Energy irradiance of the welder, $\mathrm{W} / \mathrm{m} 2$ : & & \\
\hline - in the ultraviolet part of the spectrum & 126 & 1,0 \\
\hline - in the infrared part of the spectrum & 200 & 140,0 \\
\hline
\end{tabular}

In the numerator - the average value.

In the denominator - the minimum $\div$ maximum values.

As can be seen from the table, the concentration of welding aerosol in front of and under the welder shield was, on average, 16.2 and $12.4 \mathrm{mg} / \mathrm{m} 3$, the concentration of manganese in both measurement points exceeded the MPC (maximum permissible concentration) by 46 times. Microclimate parameters and illumination levels corresponded to acceptable values $[3,4]$. The concentration of nitrogen oxides and carbon monoxide did not exceed the MPC [5]. Energy radiation in the optical range exceeded the MPL (maximum permissible level): 120 times in the ultraviolet part of the spectrum, 1.5 times in the infrared part $[3,6]$. 
According to the instrumental data, changes in the functional state of electric welders consisted in reducing the endurance of the hand muscles in combination with a constant indicator of the maze performance time with coordinate measurement and a decrease in the number of errors. There was noticed a tendency of moving the nearest point of clear vision of the left and right eyes away. The remaining indicators, on average, remained virtually unchanged (Table 2).

Table 2. Changes in the condition of the organism of the electric welders during a shift (95 personshift observations).

\begin{tabular}{|c|c|c|c|}
\hline Indicator & Beginning of shift & Middle of shift & End of shift \\
\hline $\begin{array}{c}\text { Heart rate, beats / min } \\
\text { the hand, kg }\end{array}$ & $94,5+1,3$ & $\mathrm{X}+\mathrm{mx}$ & $\mathrm{X}+\mathrm{mx}$ \\
\hline $\begin{array}{c}\text { Strength of the muscles of } \\
\text { the retention time of a } \\
\text { static force in 75\% of th } \\
\text { strength of the hand } \\
\text { muscles, sec. }\end{array}$ & $50,6+0,6$ & $49,8+1,5$ & $49,4+0,9$ \\
\hline $\begin{array}{c}\text { Coordinate measurement: } \\
\text { - maze performance time, } \\
\text { seconds }\end{array}$ & $18,2+1,2$ & $12,0+1,2$ & $13,3+0,71)$ \\
$\begin{array}{c}\text { - the number of errors } \\
\text { CFFF, Hz }\end{array}$ & $24,5+0,8$ & $32,6+1,8$ & \\
\hline $\begin{array}{c}\text { Time of simple motor } \\
\text { reaction, ms }\end{array}$ & $3,7+0,3$ & $6,6+0,5$ & $7,5,5+0,5$ \\
\hline $\begin{array}{c}\text { The nearest point of clear } \\
\text { vision: }\end{array}$ & $346+6$ & $31,4+0,8$ & $33,6+0,6$ \\
- left eye, cm & & $323+5$ & $348+4$ \\
- right eye, cm & $14,3+0,3$ & $13,5+0,6$ & $14,9+0,3$ \\
\hline $\begin{array}{c}\text { WAM } \\
\text { - well-being, cond. unit } \\
\text { - activity, cond. unit } \\
\text { - mood, cond. unit }\end{array}$ & $14,0+0,3$ & $13,5+0,6$ & $14,7+0,3$ \\
\hline
\end{tabular}

The difference compared with the beginning of the shift is reliable:

$-\mathrm{p}<0,001$

$-\mathrm{p}<0,01$

$-\mathrm{p}<0,05$

Improving the results of the test, similar to the professional actions of welders (coordinate measurement), while simultaneously reducing the endurance of the hand muscles, is generally interpreted as an indicator of general health, as the initial stage of fatigue [7]. As for the deterioration of the accommodation capacity of the eye (moving the nearest point of clear vision away), it can be attributed to the features of the visual work of the welder: the distinction of welded edges through a dark light filter turned out to be similar to work in very low light conditions.

Thus, the average data of changes in the state of welders is assessed as signs of the initial stage of fatigue. This was accompanied by quite significant and statistically reliable changes in the components of the WAM test: on average, by the end of the shift, the state of health worsened, and the activity and mood decreased. At the same time, the decrease in self-esteem of well-being was more pronounced: 0.9 cond. units in comparison with 0.4 cond. units in activity and 0.3 cond. units in mood. 
According to the results of the studies, correlations of the individual data of WAM test changes with individual changes in the state of welders according to objective methods (Table 3), as well as with data on the state of the working environment at workplaces (Table 4) were calculated. Of twenty-four correlation coefficients of table 3, twenty-one was statistically significant $(\mathrm{p}<0.05)$.

Table 3. Correlation relationships between individual changes of wam values and individual changes of indicators of the condition of the welders' organism condition to the end of the shift (number of pairs - 80).

\begin{tabular}{|l|c|c|c|}
\hline \multirow{2}{*}{ Indicators } & \multicolumn{3}{|c|}{ Correlation coefficient with changes in indicators } \\
\cline { 2 - 4 } & Well-being & Activity & Mood \\
\hline Change in heart rate & 0,371 & 0,108 & 0,348 \\
\hline $\begin{array}{c}\text { Change in muscle strength of } \\
\text { the hand }\end{array}$ & 0,405 & 0,420 & 0,212 \\
\hline $\begin{array}{l}\text { Changing the endurance of the } \\
\text { muscles of the hand }\end{array}$ & 0,278 & 0,113 & 0,298 \\
\hline $\begin{array}{l}\text { Coordination } \\
\text { - change in the maze } \\
\text { performance time }\end{array}$ & 0,496 & 0,501 & 0,503 \\
$\begin{array}{l}\text { - change in the number of } \\
\text { errors }\end{array}$ & 0,364 & 0,238 & 0,196 \\
\hline $\begin{array}{l}\text { Change of time of motor } \\
\text { reaction }\end{array}$ & 0,368 & 0,288 & 0,335 \\
\hline $\begin{array}{l}\text { Change in the nearest point of } \\
\text { clear vision: }\end{array}$ & 0,264 & & \\
- left eye \\
- right eye
\end{tabular}

$\mathrm{r} 05=0,219$

The highest correlation coefficients were found between changes in state of well-being, activity, mood and changes in the maze performance time in coordinate measurement, as well as between changes in state of well-being, activity and changes in the muscle strength of the hand.

Table 4. Correlation relationships between individual changes of wam values by the end of the shift and the indicators of the condition of the production environment at working places (number of pairs 20).

\begin{tabular}{|c|c|c|c|}
\hline \multirow{2}{*}{ Indicators } & \multicolumn{3}{|c|}{ Correlation coefficient with changes in indicators } \\
\cline { 2 - 4 } & Well-being & Activity & Mood \\
\hline $\begin{array}{c}\text { The concentration of welding } \\
\text { aerosol in the respiratory zone }\end{array}$ & 0,507 & 0,258 & 0,345 \\
\hline $\begin{array}{c}\text { Manganese concentration in the } \\
\text { respiratory zone }\end{array}$ & 0,080 & 0,001 & 0,048 \\
\hline $\begin{array}{c}\text { Energy exposure of the welder: } \\
\text { - in the ultraviolet part of the } \\
\text { spectrum } \\
\text { - in the infrared part of the } \\
\text { spectrum }\end{array}$ & 0,362 & 0,251 & 0,221 \\
\hline
\end{tabular}


Of the correlation coefficients of table 4, only one was statistically significant. This is the connection between the welding aerosol concentration in the respiratory zone and changes in well-being at the end of the shift.

\section{The discussion of the results}

Thus, the conducted studies revealed a statistically significant correlation between changes in the state of the physiological systems of the individuals studied, as well as the concentration of the welding aerosol, on the one hand, and changes in self-esteem according to the WAM test, on the other. The deterioration of well-being, decreased activity and deterioration of mood were a reflection of a combination of the initial signs of fatigue and the results of exposure to adverse conditions of the working environment, mainly high concentrations of welding aerosol. The results show high sensitivity of the standard method of self-assessment of the state of workers and the effectiveness of its independent use. [8,9] This is especially important when assessing the impact of working conditions on workers in conditions where it is impossible to carry out physiological measurements using instruments. [10]

Findings:

1. Statistically significant correlations were found between changes in physiological parameters and the concentration of welding aerosol, on the one hand, and changes in the components of the differentiated self-assessment of the functional state (WAM) test, on the other.

2. The closest relations were between the indicators that most reflect the influence of labor actions of welders: changes in the strength of the hand muscles and the maze performance time at coordinate measurement with changes, respectively, in well-being, activity and wellbeing, activity, mood. A relatively high correlation was also found between welding aerosol concentration and changes in well-being.

3. The data obtained indicate the possibility of self-use of the WAM test in diagnosing changes in the state of working people under the influence of labor activities and factors of the working environment.

\section{References}

1. V.A. Doskin, N.A. Lavrentyeva, M.P. Miroshnikov, V.V. Sharay, The Test of Differential Self-Assessment of the Functional State, Questions of Psychology, 6, 141 145 (1973)

2. Physiological research at work in the development of the protection, organization and occupational health / Guidelines // L.: 1984, p.68 All-Union Central Council of Trade Unions, All-Union Scientific and Technical Research Institute

3. V. Salkutsan, Russkova, I., \& Faustov, S. (2019). Methods for assessing safe seniority in high noise conditions. Paper presented at the IOP Conference Series: Materials Science and Engineering, 666(1) doi:10.1088/1757-899X/666/1/012102Construction Norms and Regulations 23-05-95. Natural and artificial lighting. Design standards.

4. V. A. Golod, Rudakov, M. L., \& Stepanova, L. V. (2019). Substantiation of the parameters of personal protective equipment of the employees for ensuring thermal comfort of the coal mines underground personnel. [Обоснование параметров средств индивидуальной защиты работников для обеспечения теплового комфорта подземного персонала угольных шахт] Bezopasnost' Truda v Promyshlennosti, 2019(5), 52-58. doi:10.24000/0409-2961-2019-5-52-58 
5. T. Kaverzneva, Tarkhov, D., Uljanov, A., Senchenko, V., Pshenichnaya, C., \& Alibekova, I. (2019). Criteria for ensuring acoustic safety in the assembly shops of machine-building enterprises. Paper presented at the IOP Conference Series: Materials Science and Engineering, 643(1) doi:10.1088/1757-899X/643/1/012119

6. Sanitary and epidemiological requirements for physical factors at workplaces Sanitary Regulations and Norms 2.2.43359-16

7. A. V. Andreev, Burlov, V. G., Gomazov, F. A., \& Penner, Y. A. (2019). Improving the system of higher education for enterprises of industrial and economic complex. Paper presented at the Proceedings of 2018 17th Russian Scientific and Practical Conference on Planning and Teaching Engineering Staff for the Industrial and Economic Complex of the Region, PTES 2018, 86-88. doi:10.1109/PTES.2018.8604230

8. M. Avdeeva, Leonova, N., Gomazov, F., \& Strelcova, E. (2019). The automated system of models of management of information resources of higher education institution. Paper presented at the IOP Conference Series: Materials Science and Engineering, 666(1) doi:10.1088/1757-899X/666/1/012099

9. N. M. Bozhuk, Skripnik, I. L., Ksenofontov, Y. G., Malyshev, V. P., \& Avdeeva, M. O. (2021). Integrity of information data flow in meteor communication networks. Paper presented at the IOP Conference Series: Materials Science and Engineering, 1047(1) doi:10.1088/1757-899X/1047/1/012139 